\title{
PERENIALISME PEMIKIRAN ETIKA SANTO AUGUSTINUS (Dari Theologi ke Filsafat Keabadian)
}

\author{
Bisri \\ IAIN Syekh Nurjati Cirebon
}

\begin{abstract}
Abstrak: Santo Augustinus seorang filosof abad pertengahan yang sekaligus juga seorang teolog. Ia mencari sintesis antara rasionalitas Yunani dan iman Kristiani. Meskipun iman Kristiani dan refleksi filosofis menyatu secara tak terpisahkan dalam Santo Augustinus, apa yang ditulisnya bukan hanya penting bagi teologi Kristiani, melainkan juga merupakan sumbangan besar kepada pemikiran murni filosofis, melampaui umat seimannya. Santo Augustinus tidak menulis buku khusus tentang etika - meskipun bernapaskan imannya yang kristiani - dalam struktur teoritis etika Santo Augustinus betul-betul filosofis yang tidak mengandaikan iman keprcayaan agama tertentu. Etika Santo Augustinus yang mengangkat kembali intuisi dasar Plato amat menentukan seluruh pemikiran teologi moral di Barat selanjutnya. Dalam pemikirannya tentang etika, Santo Augustinus sama sekali tidak menyinggung tentang filsafat perennial. Namun pemikiran etikanya yang yang mendasarkan pada perintah ilahi dan penyatuan manusia dengan Tuhan melalui cinta membawa pada visi filsafat perenial. Dimana ada tiga konsepsi filsafat perenial/filsafat keabadian yaitu metafisika (berorientasi pada ketuhanan), psikologi (manusia sebagai mikrokosmos) dan etika (sebagai keselarasan).
\end{abstract}

Kata kunci: Perenialisme, Etika, Teolog, dan filsafat.

\section{A. Pengertian Filsafat Perenial}

Perenialisme atau filsafat perenial adalah salah satu cabang filsafat yang sudah sangat tua umurnya. Bahkan, oleh beberapa pemikir seperti Charles B. Schmitt, misalnya, menyebutkan bahwa cabang filsafat ini sudah ada sejak zaman para pemikir paling awal. Secara etimologis, istilah 
filsafat perenial berasal dari kata Latin yakni: philosophia perennis ${ }^{1}$ yang arti harfiahnya adalah filsafat yang abadi. Menyangkut kata "abadi" ini ada dua macam interpretasi yang berbeda. Yang pertama, Menurut Jaspers bahwa pada dasarnya, filsafat, apapun bentuk atau jenisnya adalah perenial yang tidak tunduk pada perubahan atau aturan temporal. Tampaknya Jaspers tidak menerima filsafat perenial sebagai suatu sistem. Filsafat adalah kontemplasi yang berkelanjutan dan tanpa akhir terhadap misteri wujud yang eternal yang merupakan satu dan hanya satu-satunya obyek, dimana para pemikir tiap-tiap zaman memberi kontribusi yang sama-sama validnya. ${ }^{2}$

Kedua, bersebrangan dengan interpretasi dari Karl Jaspers, Charles B. Schmitt justru menganggap istilah filsafat perenial sebagai suatu proper name, yakni sebagai nama bagi suatu sistem filsafat tertentu. Schmitt menyebutkan bahwa sejak kemunculan pola-pola pemikiran filsafat perenial pada zaman dahulu (masa pemikir awal), baru pada abad ke-16, istilah filsafat perenial dipakai sebagai nama sistem filsafat ini. Istilah perenial dari jenis filsafat ini menurut Schmitt bermakna bahwa filsafat ini tetap bertahan terus sepanjang zaman dan kesejatiannya dapat diwariskan dari generasi ke generasi serta dapat melampaui kecenderungan corak filsafat yang silih berganti. Pandangan Schmitt ini ia gali dari konsepkonsep filsafat perenial dari beberapa tokoh yang secara langsung maupun tidak langsung mengindikasikan bahwa ternyata ada jenis filsafat tertentu yang disebut sebagai filsafat perenial. Tokoh-tokoh tersebut antara lain: Marcilio Ficino, giovanni pico, Agostino Steuco, Leibniz, dan masih banyak pemikir lain lagi. ${ }^{3}$

Selain memiliki dua makna diatas tentang makna perenial yaitu sebagai sifat dan sebagai proper name. Komarudin Hidayat memahami perenial sebagai istilah yang biasanya muncul dalam wacana filsafat

\footnotetext{
${ }^{1}$ Perenial berasal dari bahasa latin, perennis, yang kemudian diadopsi kedalam bahasa Inggris, berarti kekal, selama-lamanya, atau abadi. Lihat Komarudin Hidayat dan $\mathrm{M}$ Wahyuni Nafis Agama Masa Depan: Perspektif Filsafat Perenial (Jakarta: Paramadina, 1995),hlm.1.

2 Emanuel Wora, Perenialisme: Kritik Atas Modernisme dan Postmodernisme (Yogyakarta: Kanisius, 2010), hlm. 11-12.

${ }^{3}$ Ibid., hlm. 12-13.
}

YAQZHAN Volume 4, Nomor 2, Desember 2018 
agama dimana agenda yang dibicarakan adalah, pertama, tentang Tuhan, Wujud yang Absolut, sumber dari segala wujud. Tuhan Yang maha Benar adalah satu, sehingga semua agama yang muncul dari Yang Satu pada prinsipnya sama karena datang dari sumber yang sama. Kedua, filsafat perenial ingin membahas fenomena pluralisme agama secara kritis dan kontemplatif. Dalam konteks ini, setiap agama memiliki kesamaan dengan yang lain, tetapi sekaligus juga memiliki ke-khasan sehingga berbeda dari yang lain. Ketiga, filsafat perenial berusaha menelusuri akar-akar kesadaran religiusitas seseorang atau kelompok melalui simbol-simbol, ritus serta pengalaman keberagamaan. Dengan begitu secara metodologis filsafat perenial berhutang pada apa yang disebut sebagai transcendental psychology. ${ }^{4}$

Istilah filsafat perenial diduga untuk pertama kali digunakan di dunia Barat oleh seorang bernama Santo Augustinus Steuchus (1497-1548) sebagai judul karyanya, De Perenni Philosophia,yang diterbitkan pada 1540. Istilah tersebut kemudian dipopulerkan oleh Leibnitz dalam sepucuk suratnya yang ditulis pada 1715, yang menegaskan bahwa dalam membicarakan tentang pencarian jejak-jejak kebenaran di kalangan para filosof kuno dan tentang pemisahan yang terang dari yang gelap, sebenarnya itulah yang dimaksud dengan filsafat perenial. ${ }^{5}$

Namun jika dilihat dari makna, sebenarnya jauh sebelum Steuchus dan Leibnitz, agama hindu telah membicarakannya dalam istilah yang disebut Sanatana Dharma. Demikian pula di kalangan kaum muslim, mereka telah mengenalnya lewat karya Ibn Miskawaih (932-1030), alHikmat al-Khaalidah (Javidan Khirad dalam bahasa Persia), yang telah begitu panjang lebar membicarakan filsafat perenial. Dalam buku itu Ibn Miskawaih banyak membicarakan pemikiran-pemikiran dan tulisantulisan orang-orang suci dan para filosof, termasuk di dalamnya mereka yang berasal dari Persia Kuno, India dan Romawi. ${ }^{6}$

Dengan demikian filsafat perenial secara sederhana bisa kitab sebut sebagai suatu pandangan yang sebenarnya secara tradisional sudah

\footnotetext{
${ }^{4}$ Komarudin Hidayat, Agama Masa Depan, hlm. 1-2

${ }^{5}$ Ibid., hlm. 2.

${ }^{6}$ Ibid.
}

YAQZHAN Volume 4, Nomor 2, Desember 2018 
menjadi pegangan dan pandangan hidup serta dipelihara oleh mereka yang menyebut dirinya "penganut hikmah" - para gnostis dalam istilah Kristen dan para sufi dalam islam. Inti pandangan filsafat perenial adalah bahwa dalam setiap agama dan tradisi-tradisi esoterik ada suatu pengetahuan dan pesan keagamaan yang sama, yang muncul melalui beragam nama dan dibungkus dalam berbagai bentuk dan simbol. ${ }^{7}$

Dalam dunia Timur, filsafat perenial tetap langgeng karena terawat baik dalam tradisi-tradisi religius Timur yang agung. Seperti Budhisme, Islam, Taoisme, Hinduisme, dan yang lainnya lagi. Tradisi-tradisi religius Timur ini luput dari "amukan" modernisme Barat yang berhasil menghancurkan tradisi kebijaksanaan kuno yang pernah dimiliki oleh dunia Barat. ${ }^{8}$

\section{B. Pola-Pola Kebangkitan Filsafat Perenial}

Bede Griffiths mencoba mengungkapkan beberapa pola kebangkitan filsafat perenial, yang disebutnya sebagai pola-pola abad baru dalam kehidupan manusia kontemporer. pola-pola itu antara lain:

1. Adanya sebuah relasi yang baru dengan alam;

Relasi baru ini bertumpu pada pemahaman dunia yang bersifat organis yang menggantikan pandangan mekanistik yang dianut dunia modern. Semua manusia perlu mengembangkan rasa akan keseluruhan kosmis serta rasa akan sebuah cara berelasi dengan dunia disekitar mereka sebagai suatu mahluk hidup yang menopang dan menghidupi mereka

2. Adanya suatu perasaan kebersatuan (sense of communion) dengan seluruh semesta yang luas ;

Perasaan kebersatuan ini akan menggantikan atau menggeser semua kecenderungan manusia untuk menguasai alam semesta. Menggantikan teknololgi modern dengan yang lebih ramah lingkungan seperti teknologi yang ada dipedesaan seperti teknologi pemintalan sederhana, pertenunan dan teknologi

\footnotetext{
${ }^{7}$ Ibid.

${ }^{8}$ Emanuel Wora, Perenialisme, hlm. 58.
}

YAQZHAN Volume 4, Nomor 2, Desember 2018 
tembikar yang berbeda dengan teknologi yang canggih yang eksploitatif terhadap alam.

3. Munculnya suatu bentuk komunitas manusiawi yang baru.

Akumulasi berbagai nilai yang terungkap dalam dua pola kebangkitan perenialisme sebelumnya menyumbang kepada kemunculan sebuah bentuk komunitas manusiawi yang baru. Pendidikan dalam masyarakat baru ini dibuat sebagai suatu pendidikan integral yang mencakup tubuh, jiwa dan roh, serta menghubungkan setiap pribadi dengan dunia dalam suatu cara yang organis dan mengembangkan kemampuan-kemampuan pribadi mereka. ${ }^{9}$

\section{Konsep-Konsep Dasar Filsafat Perenial}

Untuk memahami seperti apa konsep dasar filsafat perennial sangat bergantung pada bagaimana kita mendefinisikan filsafat perennial itu. Memang tidaklah mudah sebagaimana dikatakan Huston Smith, menurutnya ia tidak bisa lagi menemukan rumusan yang lebih bagus, lebih jelas dan lebih sistematis daripada rumusan Aldous Huxley. ${ }^{10}$ Untuk menganalisis pemikiran perenialisme Santo Augustinus, penulis mengambil rumusan Aldous Huxley sebagai kerangka acuan untuk menjabarkan konsep-konsep dasar filsafat perennial ini yang saya kutip dari bukunya Emanuel Wora bahwa Huxley menyebut tiga konsep dasar filsafat perenial, ${ }^{11}$ yakni: ${ }^{12}$

\footnotetext{
${ }^{9}$ Ibid., hlm. 62-65.

${ }^{10}$ Konsep dasar filsafat ini selanjutnya akan dijadikan sebagai kerangka acuan untuk menganalisis makna-makna perennialis dari sebuah pemikiran. Konsep dasar ini merupakan salah satu indikator dari sifat atau karakteristik pemikiran filsafat perennial secara umum.

${ }^{11}$ Emanuel Wora, Perenialisme, hlm. 26-27.

${ }^{12}$ Dalam buku The Perennial Philosophy, Huxley tidak secara eksplisit dan sistematis membahas soal metafisika perenial ini, begitu juga dengan psikologi dan etika perenial. Ia hanya secara acak menguraikan berbagai tema dasar yang penting, yang menjadi doktrin-doktrin inti filsafat perenial. Misalnya tentang realitas ilahi , kepribadian, agama dan pengetahuan diri, rahmat dan kehendak bebas, dan beberapa tema lainnya. Ibid., hlm. 29
} 
1. Metafisika, yang mencoba mengenal suatu realitas Ilahi, yang sangat substansial bagi dunia material, kehidupan dan pikiran.

Metafisika dalam hal ini diartikan sebagai usaha sistematis dan reflektif dalam mencari hal yang ada dibalik hal-hal yang fisik dan partikular. Aldous huxley menyebutkan bahawa metafisika perenial adalah metafisika yang berusaha mengenal realitas Ilahi sebagai dasar dari dunia bendawi, hayati maupun akali. Jadi, kalau metafisika yang umum itu tidak secara langsung dan eksplisit menunjuk realitas ilahi sebagai dasar segala sesuatu, lain halnya dengan metafisika perenial, realitas yang ilahi, apapun namanya, disebut secara langsung dan secara jelas sebagai dasar dari alam semesta. $^{13}$

Filsafat perenial melihat semua realitas ini sebagai satu kesatuan dalam arti sebagai satu wujud yang hierarkis, dan wujud yang hierarkis itu pada giliranya dipahami sebagai realitas ultim. Berikut ini adalah daftar tingkatan atau hierarki realitas yang terurai dalam filsafat perenial:

a. Tuhan yang tidak mengejawantah (Godhead),

b. Tuhan yang mengejawantah (tataran surgawi/spiritual),

c. Alam dalam aspeknya yang tak terindrai, yakni akal dan prinsipal vital,

d. Alam dalam aspeknya yang terindrai: ruang, waktu dan materi. $^{14}$

2. Psikologi, yang mencoba menemukan di dalam jiwa manusia, sesuatu yang mirip, bahkan identik dengan realitas Ilahi.

Menurut karakteristiknya, psikologi perenial tidak menempatkan masalah ego yang personal sebagai tema sentralnya, melainkan masalah diri abadi atau diri ilahi yang berada didalam diri individu yang partikular. Diri ilahi ini identik atau paling tidak sama dengan Dasar ilahi (Divine ground). Aldous Huxley menyebutkan bahwa psikologi perenial ini pada dasarnya bersumber pada metafisika perenial. ${ }^{15}$

Manusia adalah mikrokosmos yang mencerminkan makrokosmos atau sebaliknya, makrokosmos itu mencerminkan manusia yang

\footnotetext{
${ }^{13}$ Emanuel Wora, Perenialisme, hlm. 28-29.

${ }^{14}$ Ibid., hlm. 30.

${ }^{15}$ Ibid., hlm. 32-33
}

YAQZHAN Volume 4, Nomor 2, Desember 2018 
mikrokosmos. Namun, antara dunia makrokosmos dan manusia tetap ada perbedaan. Dalam dunia makrokosmos, yang terbaik adalah yang menduduki hirarki tertinggi yakni realitas ilahi yang tidak terejawantahkan, namun dalam diri manusia (mikrokosmos), yang terbaik adalah yang menempati posisi terdalam, yakni roh yang bersifat Ilahi. Roh ini adalah basis fundamental dan dasar wujud kita. ${ }^{16}$

Jadi realitas ilahi itu tidak hanya ada dimana-mana diluar diri manusia, melainkan ia juga berdiam di kedalaman diri manusia. Dengan konsep ini, psikologi perenial sepertinya menerima pemahaman bahwa Yang Ilahi itu transenden dan sekaligus imanen.

3. Etika, yang menempatkan tujuan/cita-cita akhir manusia pada pengetahuan akan dasar semua being (ground of all beings)

Huston Smith mengutip dari buku Lewis, The Abolition of man, yang menyebutkan bahwa isi etika perenial ini adalah apa yang disebut sebagai Tao. ${ }^{17}$ Tao ini adalah sebuah sistem nilai yang merupakan gabungan berbagai imperatif moral dari berbagai tradisi, yang menggumpal dalam tiga kebijakan yakni: ketulusan, kerendahan hati, dan kedermawanan. Ketiga kebijakan ini dipertentangkan ${ }^{18}$ dengan tiga racun yakni: keangkuhan, ketamakan, dan kebodohan. ${ }^{19}$

\footnotetext{
${ }^{16}$ Ibid., hlm. 32

${ }^{17}$ Cerita kosmis yang muncul di Tiongkok adalah seputar Tao. Tao universal yang ada pada setiap mahluk, adalah sumber keselarasan di dalam semesta yang ada, namun tersembunyi di dalam setiap kekuatan alam. Diri sejati hanya bisa dikenali melalui keterhubungan dengan Tao. Segala penciptaan terjadi melalui kombinasi kontras yang saling melengkapi seperti yin dan yang, gelap dan terang, bumi dan langit, wanita dan pria. Yin dan Yang bukanlah poros yang bertentangan, melainkan masing-masing berjalan menuju satu sama lain tanpa pemisahan yang absolut, sebagaimana siang berganti malam dan malam berganti siang. Selalu ada sedikit siang pada malam hari, sedikit pria dalam setiap wanita (dan begitupun sebaliknya). Maka, kehidupan manusia yang ideal adalah keseimbangan dan keselarasan. Masalah utama yang kemudian dihadapi adalah ketidak selarasan yang muncul ketika elemen masyarakat dan/atau semesta tak lagi seimbang. Lihat John L. Esposito, World Religions ToDay:Agamaagama Dunia Dewasa Ini ter. Ayu Yudha dkk (Jakarta: PT. Elex Media Komputindo Kelompok Gramedia, 2012), hlm. 28.

${ }^{18}$ Simbol terkenal Tai Chi, atau Tao, melukiskan yin dan yang sebagai gerakan dan perubahan yang konstan. Dalam fenomena tertentu, hubungan antara yin dan dan yang terus menerus berubah. Karena itu, seluruh alam semesta terus berubah setiap saat, bagaikan sungai yang mengalir. Yin dan yang adalah prinsip-prinsip perubahan dan
} 
Kerendahan hati adalah kapasitas untuk membuat jarak antara diri seseorang dengan urusan pribadinya, menjauhkan ego supaya ia bisa melihat secara objektif dan akurat. Sedangkan ketulusan adalah kemampuan untuk mengetahui benda-benda alam apa yang disebut Budhisme sebagai keadaan pada dirinya, yakni kondisi dimana mereka berada secara aktual, objektif dan akurat. Sementara kedermawanan adalah melihat orang lain seperti diri sendiri. Ketiga kebijakan utama tadi sangat berkaitan dengan tatanan manusiawi. ${ }^{20}$

Etika perenial ini sama sekali tidak menolak adanya relasi interpersonal, sebab tujuan utama dari etika perenial ini adalah suatu keselarasan kosmis, sebagai hasil dari ketiga kebijakan tadi. Keselarasan kosmis yang dimaksud etika perenial tidak lain dan tidak bukan adalah kesadaran akan kesatuan dengan realitas ilahi yang menjadi dasar segala sesuatu. ${ }^{21}$

\section{Tentang Santo Augustinus}

Santo Augustinus adalah seorang filosof abad pertengahan, ia seorang Afrika Utara, lahir di Teges $354 \mathrm{M}$, sebuah kota kecil di dekat kota karthago, yang letaknya di dekat kota Tunis sekarang. Ibunya Kristen, ayahnya masih menganut agama Rpmawi kuno. Santo Augustinus memperoleh pendidikan yang baik dan menjadi seorang guru ilmu bicara (rethor). Santo Augustinus sendiri di dalam Gereja dianggap sebagai orang yang suci, karena itu disebut Santo Santo Augustinus. Sekaligus ia salah satu dari "guru-guru besar" umat Kristiani. Santo Augustinus menulis dalam bahasa latin, bukan dalam bahasa Yunani. Pemikirannya

simbol bagi seluruh gerak di alam semesta. Ketika matahari terbit, rembulan pun tenggelam. Kala musim semi tiba, musim dingin pun beranjak pergi. Keduanya tidak untuk diperlawankan melainkan keselarasan dan keseimbangan. Dalam kata-kata Confucius "Bagaikan sebuah sungai yang mengalir, seluruh alam semesta terus menerus mengalir siang dan malam." Eksistensi berarti perubahan harmonis dengan berpijak pada tao. Jika harmoni antara yin dan yang hilang, maka alam semesta akan berhenti mengalir dan tak bakal ada sesuatupun. Lihat Sachiko Murata, The Tao Of Islam:Kitab Rujukan Tentang Relasi Gener dalam Kosmologi dan Teologi Islam (Bandung: Mizan, 1996), 28.

${ }^{19}$ Emanuel Wora, Perenialisme, hlm. 34-35.

${ }^{20}$ Ibid., hlm. 35.

${ }^{21}$ Ibid.

YAQZHAN Volume 4, Nomor 2, Desember 2018 
betul-betul menguasai teologi di Gereja Barat sampai abad ke-13; sejak itu pengaruhnya semakin akan diimbangi oleh pemikiran Thomas Aquinas. Namun sampai hari ini Santo Augustinus tetap termasuk pemikir paling berpengaruh dalam budaya Kristiani Barat, terutama dalam pelbagai aliran Protestantisme.

Sebagai seorang muda ia tertarik kepada aliran Manikeisme, suatu aliran berasal dari Persia yang ajarannya dualistik. Aliran ini menyatakan bahwa realita terdiri atas dua prinsip dasar: yang baik, yaitu cahaya, Allah, atau roh, dan yang jahat, kegelapan atau materi. Saat berumur 28 tahun, ia pindah ke Roma. Disitu ia melepaskan manikeisme. Sesudah selama beberapa waktu menganut skeptisisme, ia berkenalan dengan neoplatonisme yang amat menarik baginya. Ia pindah ke Milano dan disitu, dibawah pengaruh uskup Ambrosius, Santo Augustinus dibaptis, lalu pulang ke Afrika. Ia dipilih oleh umat menjadi uskup di kota Hippo. Itulah waktu ia, disamping tugas-tugasnya sebagai gembala umagt, akan banyak mengarang tulisan dalam bidang spiritualitas dan teologi. Karya utama Santo Augustinus adalah Confessiones ("Pengakuan"), otobiografi pertama yang kita kenal dalam sejarah sastra, dan De Civitate Dei ("Tentang Komunitas Allah"), yang ditulisnya dibawah kejutan penjarahan kota Roma oleh pasukan suku Got pada tahun 410M. ${ }^{22}$

Santo Augustinus sekaligus seorang filosof dan teolog. Ia mencari sintesis antara rasionalitas ${ }^{23}$ Yunani dan iman Kristiani. Meskipun iman Kristiani dan refleksi filosofis menyatu secara tak terpisahkan dalam Santo Augustinus, apa yang ditulisnya bukan hanya penting bagi teologi Kristiani, melainkan juga merupakan sumbangan besar kepada pemikiran murni filosofis, melampaui umat seimannya. Santo Augustinus tidak menulis buku khusus tentang etika - meskipun bernapaskan imannya yang kristiani - dalam struktur teoritis etika Santo Augustinus betul-betul filosofis yang tidak mengandaikan iman keprcayaan agama tertentu. Etika

\footnotetext{
${ }^{22}$ Franz Magnis Suseno, 13Tokoh Etika: Sezak Zaman Yunani Sampai Abad ke-19 (Yogyakarta: Penerbit Kanisius, 1997), hlm. 65.

${ }^{23}$ Ibid., hlm. 65-66.
}

YAQZHAN Volume 4, Nomor 2, Desember 2018 
Santo Augustinus yang mengangkat kembali intuisi dasar Plato amat menentukan seluruh pemikiran teologi moral di Barat selanjutnya. ${ }^{24}$

\section{E. Etika Santo Augustinus}

\section{Kebahagiaan dan Transendensi}

Seperti seluruh etika sebelumnya, ${ }^{25}$ bagi Santo Augustinus hidup yang baik dalam arti moral adalah hidup menuju kebahagiaan itulah tujuan manusia. Dan etika ${ }^{26}$ mengajarkan jalan ke tujuan itu. Karena itu, etika dalam pengertian Santo Augustinus adalah ajaran tentang hidup yang bahagia.

Meskipun titik tolak etika Santo Augustinus sama dengan etika Yunani sebelumnya, pada Santo Augustinus terdapat dimensi baru yang

\footnotetext{
${ }^{24}$ Ibid., hlm. 66.

${ }^{25}$ Sokrates, Plato dan sejumlah pemikir kuno lainnya semua mendekati etika dengan mempertanyakan: Sifat karakter macam apakah yang membuat seseorang menjadi pribadi yang baik? Hasilnya, "keutamaan-keutamaan" menempati pusat panggung dalam diskusi mereka.

Dalam perjalanan waktu, cara berfikir mengenai etika seperti ini ternyata diabaikan. Dengan munculnya Kristianisme, seperangkat gagasan mulai diperkenalkan. Orang-orang Kristen, seperti halnya orang yahudi, merupakan pemeluk monoteis yang memandang Allah sebagai pemberi hukum, dan bagi mereka hidup yang benar berarti taat pada perintah ilahi. Orang-orang Yunani memandang akal budi sebagai sumber dari kebijakan praktis - kehidupan utama menurut mereka, kalau demikian, tak terpisahkan dari kehidupan akal. Tetapi Santo Santo Augustinus, pemikir Kristen abad ke-4 yang besar pengaruhnya kurang mempercayai akal dan mengajarkan bahwa kebaikan moral tergantung pada sub ordinasi diri kepada Allah. Lihat, James Rachels, The Elements of Moral Philosophy: Filsafat moral ter. A. Sudiarja (Yogyakarta: Penerbit Kanisius, 2004), hlm. 307.

${ }^{26}$ Istilah "etika" berasal dari Yunani Kuno. Kata Yunani ethos dalam bentuk tunggal mempunyai banyak arti: tempat tinggal yang biasa; padang rumput; kandang habitat; kebiasaan, adat; akhlak, watak; perasaan, sikap, cara berfikir. Dalam bentuk jamak (ta etha) artinya adalah: adat kebiasaan. Dan arti terakhir inilah menjadi latar belakang bagi terbentuknya istilah "etika" yang oleh filosof besar Yunani Aristoteles 9384-322 SM) sudah dipakai untuk menunjukkan filsafat moral. Lihat, K. Bertens, Etika (Jakarta: Gramedia Pustaka Utama, 2011), hlm. 4.
}

YAQZHAN Volume 4, Nomor 2, Desember 2018 
secara radikal mengubah seluruh sepak terjang dan warna etika, yaitu kesadaran akan Transendensi. Itu tentu akibat dari iman Kristiani Santo Augustinus. Perspektif etika Yunani adalah kehidupan di dunia ini. Tentang keadaan sesudah kematian, filsafat Yunani diam. Keadaan itu tidak dianggap relevan bagi bagaimana manusia harus hidup di dunia ini. Adapun sebagai orang yang percaya kepada Allah, bagi Santo Augustinus manusia mencapai identitas definitifnya justru apabila iaberhadapan dengan Penciptanya, Allah, jadi diseberang hidup ini. Transendensi manusia itu berakar dalam transendensi Allah. Karena itu, yang membedakan etika Santo Augustinus dari etika filsafati barat sebelumnya adalah dimensi transendensi. ${ }^{27}$

Allah yang diyakini Santo Augustinus bukan sebuah prinsip abstrak atau semacam daya komis, melainkan Allah yang personal dalam arti Allah yang menyapa manusia, yang mengarahkan kehidupannya, yang turut campur dalam sejarah hidup manusia (melalui para nabi, melalui wahyu yang semua peristiwa historis dan bukan mitos). Jelaslah kalau ada Allah dan Allah menyapa manusia ciptaan-Nya, makna kebahagiaan manusia tidak dapat dicari di luar Allah. Hanya dalam Allah, manusia dapat mencapai kebahagiaannya. ${ }^{28}$

\section{Menyatunya Nilai Objektif dan Subyektif}

a. Allah merupakan kebahagiaan manusia dari dua sudut, secara obyektif dan secara subyektif. Secara obyektif Allah dalah Nilai tertinggi. Tak ada yang baik kecuali karena kaitannya dengan Allah. Apapun yang baik karena mendapat kebaikannya dari Allah, apapun yang bernilai, berniali karena berpartisipasi dalam nilai mutlak, yaitu Allah. Allah adalah prinsip terakhir segala nilai moral. ${ }^{29}$

Namun, karena manusia diciptakan Allah. Hakikat manusia senantiasa sudah mengarah kepada Allah. Allah adalah rahasia hakikat manusia. Karena itu, menurut Santo Augustinus manusia secara batin selalu sudah tertarik kepada Allah. Itu juga berarti bahwa ia tertarik kepada yang baik. Ada banyak hal yang baik bagi manusia. Manusia

\footnotetext{
${ }^{27}$ Franz Magnis Suseno, 13Tokoh Etika., hlm. 67.

${ }^{28}$ Ibid.

${ }^{29}$ Ibid.
}

YAQZHAN Volume 4, Nomor 2, Desember 2018 
malah dapat tersesat dengan mengejar segala nilai itu kalau ia tidak menempatkannya ke dalam perspektif nilai mutlak. Namun, nilai yang paling dalam bagi manusia adalah sumber eksistensinya, yang juga menyelamatkannya, yaitu Allah. Jadi, menusia sedalam-dalamnya tertarik kepada Allah. ${ }^{30}$

b. Plato juga sudah merasakan ketertarikan itu. Namun, ia masih memahaminya secara intelektual belaka, sebagai ketertarikan jiwa manusia kepaa idea Yang Baik. Santo Augustinus tahu bahwa dengan daya pikir kita tidak betul-betul dapat sampai kepada Allah. Kita hanya dapat sampai kepada Allah dengan dorongan hati kita, yaitu dengan Kehendak. Kehendak itu adalah cinta. Di dunia ini kita tidak dapat melihat Allah, tetapi kita sudah dapat mencintai-Nya. Bahkan, menurut Santo Augustinus segala dorongan hati yang sering kemana-mana sebenarnya merupakan gerakan ke arah Allah, tanpa kita menyadarinya. Allah berada di lubuk hati manusia. Segala kerinduan, kegelisahan dan hasrat hati sebenarnya mengungkapkan fakta yang paling mendasar; bahwa hati kita tertarik oleh nilai tertinggi yang ada, Allah. Dalam Confessiones kita menemukan kata indah Santo Augustinus: "Engkau menciptakan kami bagi Engkau, ya Allah, dan hati kami resah sampai beristirahat dalam DiriMu. $" 31$

c. Kebahagiaan yang sebenarnya justru terletak dalam menyatunya nilai objektif dan nilai subjektif itu, dalam menyatunya dorongan hati, yaitu Cinta Kasih, dengan sumber dan tujuan objektifnya, yaitu Allah. Dalam Allah, tujuan kita, keberhasilan hidup menyatu dengan idea Yang Baik, pencapaian identitas kita sepenuhnya dengan nilai tertinggi obyektif. Makin kuat hati orang diresapi oleh cinta kepada Allah, makin lurus dan betul arah kehidupannya. ${ }^{32}$

\section{Hukum Ilahi dan Dinamika Batin Manusia}

\footnotetext{
${ }^{30}$ Ibid., hlm. 67-68.

${ }^{31}$ Ibid., hlm. 68.

32 Ibid., hlm. 69.
}

YAQZHAN Volume 4, Nomor 2, Desember 2018 
a. Untuk menerjemahkan cinta kepada Allah $^{33}$ kedalam sikap dalam kehidupan sehari-hari, menurut Santo Augustinus kita harus memperhatikan Tatanan Cinta(ordo amoris). Tolok ukur cinta adalah tatanan realitas di dunia dan di alam baka. Sikap kita adalah betul apabila sesuai dengan nilai masing-masing unsur dalam tatanan itu. Seluruh realitas mencerminkan kehendak Allah Sang Pencipta. Allah menghendaki agar sikap yang kita ambil terhadap apa yang diciptakan-Nya itu sesuai dengan kehendak-Nya. ${ }^{34}$

b. Menurut tatanan cinta, manusia hendaknya mendahulukan apa yang lebih tinggi dalam tatanan itu. Cinta paling bawah adalah cinta pada barang-barang dunia yang akan hancur. Lebih dari benda duniawi, manusia hendaknya mencintai diri sendiri dan sesamanya. Cinta yang paling luhur adalah cinta kepada Allah. Dalam mencintai Allah tidak ada ukuran lagi - seperti cinta kepada sesama hendaknya sama ukurannya dengan cinta kepada diri sendiri - maka Allah hendaknya dicintai tanpa ukuran sama sekali. ${ }^{35}$

Menurut Santo Augustinus, dibedakan antara hal-hal yang bernilai hanya sebagai sarana dan hal-hal yang bernilai pada dirinya sendiri. Benda-benda materiil yang tidak bertahan lebih harus kita pakai daripada kita nikmati. Semakin tinggi derajat pengada, semakin ia tidak lagi untuk dipakai, melainkan untuk dinikmati. Menikmati berarti mengakui nilai intrinsik objek yang dinikmati, berarti menyatunya kehendak dengan objeknya. Apabila kita menyatu dengan apa yang kita cintai, kita menikmatinya. Karena itu, kita boleh menikmati keindahan alam,

\footnotetext{
33 Terkait dengan cinta kepada Allah, Ibnu Arabi mengenal tiga macam cinta yang dinamakannya cinta natural, cinta spiritual dan cinta kudus. Dengan cinta kudus ia maksudkan cinta esensial dari Yang Esa..cinta abadi yang merupakan sumber dari semua macam cinta. Dengan cinta spiritual dimaksudkannya cinta mistikal yang hasil akhirnya adalah realisasi dari kesatuan esensial dari yang mencintai dan yang dicintai. Ini bukan cinta manusia, kata Ibnu Arabi, yang membawa si mistik dekat dengan Tuhan dan membuatnya satu dengan Dia; sebagaimana sebelumnya, menyadari keafinitasannya sebagai suatu "bentuk" dengan cinta universal sebagai keseluruhan. Inilah jenis cinta yang paling sempurna. Lihat, A.E. Affifi, Filsafat Mistis Ibnu Arabi (Jakarta: Gaya Media Pratama, 1995), hlm. 236.

${ }^{34}$ Franz Magnis Suseno, 13Tokoh Etika., hlm. 69

${ }^{35}$ Ibid., hlm. 69-70.
}

YAQZHAN Volume 4, Nomor 2, Desember 2018 
kecanggihan hasil kerajinan manusia, keselarasan jasmani dan keagungan jiwa manusia. Yang penting, kita memakai serta menikmati ciptaan sesuai dengan derajatnya dalam tatanan cinta itu.

c. Menaati hukum abadi dalam tatanan cinta itu bukan sesuatu yang dari luar dibebankan kepada kita, sesuatu yang heteronom dalam arti Kant, seakan-akan kita taat kepada hukum abadi karena dari luar diperintahkan oleh Allah, melainkan: Karena Allah adalah prinsip terakhir segala yang baik dan karena kita tertarik secara kodrati kepada Allah, kita juga tertarik dalam hati sendiri untuk menaati hukum Allah dalam ciptaan. Hukum Moral, yaitu Hukum Abadi Ilahi, tertera dalam hati kita. Menaati hukum moral adalah dorongan hati kita sendiri karena sama artinya dengan menanggapi nilai yang ada didalamnya dengan semestinya. ${ }^{36}$

Menurut Santo Augustinus, kita dengan sendirinya tertarik kepada yang baik. Ada suatu dinamika batin yang menarik kita untuk bertindak sesuai dengan nilai-nilai dan norma-norma moral. Sebagaimana dengan benda materiil dengan sendirinya menuju tempat yang tepat, misalnya api ke atas dan batu ke bawah, begitu pula hati tertarik kepada yang bernilai moral. Kesadaran itu kemudian akan diangkat kembali oleh Pascal sebagai "logika hati", oleh Brentano dalam paham "hidup yang betul", dan oleh Scheler sebagai "apriori nilai".

\section{Tekanan pada Kehendak}

a. Santo Augustinus sangat menekankan kepada Kehendak; dalam hal ini, ia sangat berbeda dengan intelektualisme etika Yunani. Hukum ilahi tidak berjalan seakan-akan dengan otomatis. Kehendak manusia bebas. Karena itu, manusia dapat mentatati hukum ilahi, tetapi ia juga dapat tidak menaatinya. Bahwa manusia mempunyai kehendak yang bebas berarti bahwa manusia dapat memilih antara yang baik dan yang buruk. Yang menentukan kualitas seseorang adalah kehendak atau cinta, bukan tindakan lahiriah atau hasil lahiriah tindakannya. Jadi, sikap hati yang menentukan. ${ }^{37}$

b. Dengan demikian, Santo Augustinus Menolak segala Etika Sukses. Etika sukses adalah etika yang didalamnya nilai moral; tindakan

\footnotetext{
${ }^{36}$ Ibid., hlm. 70.

${ }^{37}$ Ibid., hlm. 71.
}

YAQZHAN Volume 4, Nomor 2, Desember 2018 
mau diukur dari hasil yang tercapai dengannya. Tentu saja, sejauh tergantung dari kita, kita harus berusaha sekuat tenaga agar maksud baik kita menjadi kenyataan. ${ }^{38}$

Begitu pula, kehendak dan bukan tindakan lahiriah menentukan nilai moral manusia. Sama seperti diatas, suatu kehendak yang sungguhsungguh dengan sendirinya mencari realisasio dalam tindakan yang sesuai. Menghendaki tanpa bertindak sesuai dengan kehendak itu tidak mungkin.

Menurut Santo Augustinus, Allah melihat hati orang, dan hati orang itulah yang menentukan. Yang menentukan adalah sikap dan maksud batin. Paham itu - yang sejak Kant disebut Gessinnungethik,etika sikap hati - menolak suatu moralitas yang secara ekslusif mementingkan pemenuhan lahiriah hukum. Bukan berarti segi lahiriah boleh dilalaikan. Namun, nilai moral manusia ditentukan oleh sikap hati, oleh kehendaknya. ${ }^{39}$

Kehendak sendiri perlu dilihat dalam hubungannya dengan keterarahan batin yang lebih mendalam. Mengambil sikap tertentu bukan sesuatu yang sama sekali kebetulan dan unik, melainkan tidak miungkin lepas dari arah atau arus bawah batin manusia. Dari hati yang baik keluar perbuatan yang baik. Semakin hati dalam cinta terarah kepada Allah, semakin segala perbuatan dengan sendirinya akan mencerminkan keterarahan hati itu. Karena itu, Santo Augustinus berani mengatakan, “Cintailah, dan lakukan saja apa yang kau kehendaki!”. Maksudnya, orang yang hatinya dalam cinta sudah terorientasi seluruhnya pada nilai tertinggi, Allah, tidak lagi perlu bertanya apa sesuatu itu boleh atau tidak, sesuai atau tidak dengan huruf hukum; ia selalu akan "tahu" dan merasakan perbuatan mana baik dan benar, mana yang sesuai dengan hukum Allah. Cinta kasih membebaskan dari hukum. ${ }^{40}$

\section{F. Pernialisme Dalam Etika Santo Augustinus}

Dalam pemikirannya tentang etika, Santo Augustinus sama sekali tidak menyinggung tentang filsafat perennial. Namun pemikiran etikanya

\footnotetext{
${ }^{38}$ Ibid.

${ }^{39}$ Ibid., hlm. 72.

${ }^{40}$ Ibid.
}

YAQZHAN Volume 4, Nomor 2, Desember 2018 
yang yang mendasarkan pada perintah ilahi ${ }^{41}$ dan penyatuan manusia dengan Tuhan melalui cinta membawa pada visi perenial.

Untuk itu dalam menganalisis pemikiran perenialisme etika Santo Augustinus, penulis mengambil rumusan Aldous Huxley sebagai kerangka acuan untuk menjabarkan konsep-konsep dasar filsafat perennial ini yang saya kutip dari bukunya Emanuel Wora bahwa Huxley menyebut tiga konsep dasar filsafat perenial, yakni: Metafisika, yang mencoba mengenal suatu realitas Ilahi, yang sangat substansial bagi dunia material, kehidupan dan pikiran. Psikologi, yang mencoba menemukan di dalam jiwa manusia, sesuatu yang mirip, bahkan identik dengan realitas Ilahi. Etika, yang menempatkan tujuan/cita-cita akhir manusia pada pengetahuan akan dasar semua being (ground of all beings)

\section{Metafisika (Tuhan Sebagai Orientasi dan Dasar Tujuan Etika Santo Augustinus)}

Metafisika sebagai salah satu konsep dasar perenial dalam hal ini diartikan sebagai usaha sistematis dan reflektif dalam mencari hal yang ada dibalik hal-hal yang fisik dan partikular. Aldous huxley menyebutkan bahawa metafisika perenial adalah metafisika yang berusaha mengenal realitas Ilahi sebagai dasar dari dunia bendawi, hayati maupun akali. Filsafat perenial melihat semua realitas ini sebagai satu kesatuan dalam arti sebagai satu wujud yang hierarkis, dan wujud yang hierarkis itu pada giliranya dipahami sebagai realitas ultim.

Kita dapat melihata sisi metafisika dari etika Santo Augustinus bahwa tujuan etika adalah kebahagiaan, dan kebahagiaan tertinggi adalah Allah. Karena secara obyektif bahwa Allah adalah Nilai Tertinggi. Hakikat manusia senantiasa sudah mengarah kepada Allah. Karena itu, menurut Santo Augustinus manusia secara batin selalu sudah tertarik kepada Allah. Manusia malah dapat tersesat bila dengan mengejar segala nilai selain itu.

Dari dasar awal etika Santo Augustinus nampak jelas bahwa secara naluriah manusia sudah tertarik dan tertuju pada Tuhan sebagai Nilai tertinggi. Ini artinya bahwa orientasi etika dalam kehidupan manusia

${ }^{41}$ James Rachels, Filsafat Moral., hlm. 307.

YAQZHAN Volume 4, Nomor 2, Desember 2018 
bagi Santo Augustinus adalah Tuhan. Dan sebagaimana dijelaskan Aldous Huxley bahwa diantara ciri yang menjadi prinsip dasar perenial yaitu metafisika, yang menjadikan Tuhan sebagai dasar pemahaman dunia bendawi, hayati maupun akali.

Dalam bagian lain Santo Augustinus menguatkan akan dorongan hati manusia kepada Tuhan. Ia mengatakan bahwa manusia hanya dapat sampai kepada Allah dengan dorongan hatinya, yaitu berupa kehendak. Kehendak itu adalah cinta. Di dunia ini kita tidak dapat melihat Allah, tetapi kita sudah dapat mencintai-Nya. Bahkan, menurut Santo Augustinus segala dorongan hati yang sering kemana-mana sebenarnya merupakan gerakan ke arah Allah, tanpa kita menyadarinya. Allah berada di lubuk hati manusia. Segala kerinduan, kegelisahan dan hasrat hati sebenarnya mengungkapkan fakta yang paling mendasar; bahwa hati kita tertarik oleh nilai tertinggi yang ada, Allah. Dalam Confessiones kita menemukan kata indah Santo Augustinus: "Engkau menciptakan kami bagi Engkau, ya Allah, dan hati kami resah sampai beristirahat dalam Diri-Mu."

\section{Psikologi (Penyatuan Manusia dan Tuhan Melalui Cinta} Sebagai Etika Tertinggi yang Membebaskannya dari Bahasa Hukum)

Psikologi dalam pemahaman filsafat perenial tidak menempatkan masalah ego yang personal sebagai tema sentralnya, melainkan masalah diri abadi atau diri ilahi yang berada didalam diri individu yang partikular. Manusia adalah mikrokosmos yang mencerminkan makrokosmos atau sebaliknya, makrokosmos itu mencerminkan manusia yang mikrokosmos. Namun, antara dunia makrokosmos dan manusia tetap ada perbedaan.

Jadi realitas ilahi itu tidak hanya ada dimana-mana diluar diri manusia, melainkan ia juga berdiam di kedalaman diri manusia. Dengan konsep ini, psikologi perenial sepertinya menerima pemahaman bahwa Yang Ilahi itu transenden dan sekaligus imanen.

Santo Augustinus dalam pemikirannya tentang etika terkait hubungan antara manusia dengan Tuhan tidak sebagaimana Ibnu Arabi yang eksplisit berbicara tentang penyatauan (ittihad) antara Tuhan dan 
hamba. Jika dalam perenial manusia digambarkan sebagai mikro kosmos, maka makrokosmos dalam teosofi cahaya Ibnu Arabi sebagai metafor cermin dan bayangan Tuhan. Ibnu Arabi menyimpulkan bahwa dunia hanyalah representasi belaka, tidak ada eksistensi substansial. ${ }^{42}$ Manusia sebagai mikrokosmos merupakan representasi mikro dan entitas sempurna dari bayangan Tuhan.

Dalam hal etika, Santo Augustinus berorientasi pada kebahagian, dan kebahagiaan tertinggi adalah Tuhan. Secara naluriah, manusia sudah terhubung dengan Tuhan melalui kehendak dan cinta. Kehendak sendiri perlu dilihat dalam hubungannya dengan keterarahan batin yang lebih mendalam. Mengambil sikap tertentu bukan sesuatu yang sama sekali kebetulan dan unik, melainkan tidak miungkin lepas dari arah atau arus bawah batin manusia. Dari hati yang baik keluar perbuatan yang baik. Semakin hati dalam cinta terarah kepada Allah, semakin segala perbuatan dengan sendirinya akan mencerminkan keterarahan hati itu. Karena itu, Santo Augustinus berani mengatakan, "Cintailah, dan lakukan saja apa yang kau kehendaki!". Maksudnya, orang yang hatinya dalam cinta sudah terorientasi seluruhnya pada nilai tertinggi, Allah, tidak lagi perlu bertanya apa sesuatu itu boleh atau tidak, sesuai atau tidak dengan huruf hukum; ia selalu akan "tahu" dan merasakan perbuatan mana baik dan benar, mana yang sesuai dengan hukum Allah. Cinta kasih membebaskan dari hukum.

\section{Etika (Kualitas Cinta dalam Etika sebagai Keselarasan antara Kehendak dan Tindakan lahiriah)}

Etika perenial ini sama sekali tidak menolak adanya relasi interpersonal, sebab tujuan utama dari etika perenial ini adalah suatu keselarasan kosmis, sebagai hasil dari ketiga kebijakan tadi. Keselarasan kosmis yang dimaksud etika perenial tidak lain dan tidak bukan adalah kesadaran akan kesatuan dengan realitas ilahi yang menjadi dasar segala sesuatu.

Santo Augustinus dalam etikanya sangat menekankan kepada kehendak; dalam hal ini, ia sangat berbeda dengan intelektualisme etika

${ }^{42}$ Henry Corbin, Creative imaginationin The Sufisme of Ibnu Arabi: Imajinasi Kreatif Sufisme Ibnu Arabi. Ter. Moh. Khozim dan Suhadi (Yogyakarta: LkiS, 2002), hlm. 246247.

YAQZHAN Volume 4, Nomor 2, Desember 2018 
Yunani. Hukum ilahi tidak berjalan seakan-akan dengan otomatis. Kehendak manusia bebas. Karena itu, manusia dapat mentatati hukum ilahi, tetapi ia juga dapat tidak menaatinya. Bahwa manusia mempunyai kehendak yang bebas berarti bahwa manusia dapat memilih antara yang baik dan yang buruk. Yang menentukan kualitas seseorang adalah kehendak atau cinta, bukan tindakan lahiriah atau hasil lahiriah tindakannya. Jadi, sikap hati yang menentukan.

Walaupun etikanya menekankan pada kehendak sebagai penentu nilai dan bukannya tindakan lahiriah, namun bukan berarti mengabaikan makna dari tindakan lahiriah itu sendiri. Sebab bagi Santo Augustinus, bahwa duatu kehendak yang sungguh-sungguh dengan sendirinya mencari realisasi dalam tindakan yang sesuai. Bahwa yang menentukan nilai moral adalah bukan tindakan lahiriah melainkan kehendak. Namun hanya kehendak yang benar-benar dan sungguh-sungguh yang hanya dapat merealisasikan diri dalam bentuk tindakan lahiriah yang sesuai. Inilah wujud keselarasan antara kesungguhan kehendak dan tindakan lahiriah dalam etika Santo Augustinus.

\section{E. Dari Teologi Ke Filsafat Keabadian}

Orientasi filsafat mengalami perubahan dari fase awal yaitu zaman Yunani kuno dimana obyek pemikiran filsafat adalah masalah alam. Pada fase atau zaman ini biasanya disebut dengan kosmosentris, yaitu karena yang menjadi persoalan pada saat itu adalah pertanyaan tentang "Apa bahan dasar dari penciptaan alam semesta?". Selanjutnya pada abad pertengahan di Barat dimana mulai masuk dan berkembangnya agama Kristen, arah orientasi filsafat berubah kepada persoalan teologi dan ketuhanan ajaran al-Kitab. Zaman ini biasa diebut dengan teosentris. Filsafat pada masa ini disebut juga dengan istilah filsafat patristik, dari kata Latin pater yaitu bapa. Yang dimaksud ialah para bapa Gereja. Maka pada masa ini filsafat berubah warnanya lebih bercorak ke teologis.

Santo Augustinus seorang filosof abad pertengahan yang sekaligus juga seorang teolog. Ia mencari sintesis antara rasionalitas Yunani dan iman Kristiani. Meskipun iman Kristiani dan refleksi filosofis menyatu secara tak terpisahkan dalam Santo Augustinus, apa yang ditulisnya bukan 
hanya penting bagi teologi Kristiani, melainkan juga merupakan sumbangan besar kepada pemikiran murni filosofis, melampaui umat seimannya. Santo Augustinus tidak menulis buku khusus tentang etika meskipun bernapaskan imannya yang kristiani - dalam struktur teoritis etika Santo Augustinus betul-betul filosofis yang tidak mengandaikan iman keprcayaan agama tertentu. Etika Santo Augustinus yang mengangkat kembali intuisi dasar Plato amat menentukan seluruh pemikiran teologi moral di Barat selanjutnya. ${ }^{43}$

Santo Santo Augustinus pada umumnya tidak mencurahkan pemikirannya pada filsafat murni, namun disaat ia melakukannya, ia menunjukkan kemampuan yang sangat besar. Ia adalah orang pertama dari barisan panjang para pemikir yang pandangan-pandangan spekulatifnya yang murni dipengaruhi oleh keperluan untuk menyelaraskan diri dengan kitab suci. Hal ini tidak terjadi pada para filosof Kristen yang lebih awal, misalnya Origen; pada Origen, Kristianitas dan platonisme letaknya saling berdampingan, dan tidak saling meresapi. Pada Santo Augustinus, dilain pihak, pemikiran orisinal dalam filsafat murni dipicu oleh fakta bahwa Platonisme, pada segi-segi tertentu, tidak selaras dengan kitab kejadian. ${ }^{44}$ Namun demikian, Santo Augustinus tetap menampilkan pemikiran filsafatnya yang murni dalam etikanya yang memuat karakteristik dasar dari filsafat perenial atau filsafat keabadian. Dimana ada tiga konsepsi filsafat perenial/filsafat keabadian yaitu metafisika (berorientasi pada ketuhanan), psikologi (manusia sebagai mikrokosmos) dan etika (sebagai keselarasan).

\footnotetext{
${ }^{43}$ Franz Magnis Suseno, 13 Tokoh Etika, hlm. 66.

${ }^{44}$ Betrand Russell, History of western Philosophy and its Connection with Political and Social Circumtances From The Earliest Times to The Present Day: Sejarah Filsafat barat: Kaitannya dengan kondisi Sosio-Politik Zaman Kuno Hingga Sekarang ter. Sigit Jatmiko, dkk. (Yogyakarta: Pustaka Pelajar, 2007), hlm. 474.

YAQZHAN Volume 4, Nomor 2, Desember 2018
} 


\section{DAFTAR PUSTAKA}

Affifi, A.E., 1995. Filsafat Mistis Ibnu Arabi Jakarta: Gaya Media Pratama.

Bertens, K., 2011. Etika Jakarta: Gramedia Pustaka Utama.

Corbin, Henry, 2002, Creative imaginationin The Sufisme of Ibnu Arabi: Imajinasi Kreatif Sufisme Ibnu Arabi. Ter. Moh. Khozim dan Suhadi Yogyakarta: LkiS.

Esposito, John L., 2012, World Religions ToDay:Agama-agama Dunia Dewasa Ini ter. Ayu Yudha dkk Jakarta: PT. Elex Media Komputindo Kelompok Gramedia.

Hidayat, Komarudin dan M Wahyuni Nafis, 1995, Agama Masa Depan: Perspektif Filsafat Perenial Jakarta: Paramadina.

Murata, Sachiko, 1996, The Tao Of Islam:Kitab Rujukan Tentang Relasi Gener dalam Kosmologi dan Teologi Islam Bandung: Mizan.

Rachels, James, 2004. The Elements of Moral Philosophy: Filsafat moral ter. A. Sudiarja Yogyakarta: Penerbit Kanisius.

Russell, Betrand, 200, 7 History of western Philosophy and its Connection with Political and Social Circumtances From The Earliest Times to The Present Day: Sejarah Filsafat barat: Kaitannya dengan kondisi Sosio-Politik Zaman Kuno Hingga Sekarang ter. Sigit Jatmiko, dkk. Yogyakarta: Pustaka Pelajar.

Suseno, Franz Magnis, 1997. 13Tokoh Etika: Sezak Zaman Yunani Sampai Abad ke-19 Yogyakarta: Penerbit Kanisius.

Wora, Emanuel, 2010 Perenialisme: Kritik Atas Modernisme dan Postmodernisme Yogyakarta: Kanisius. 